\title{
Behavioral Contracts to Minimize Smartphone Rescue for Student Study Time at Home
}

\author{
Yuyun Nuriyah Muslih
}

\author{
Sekolah Tinggu Agama Islam Nahdlatul Ulama (STAINU) Tasikmalaya Indonesia \\ yuyunnuriyahmuslih@gmail.com
}

Submitted : 2019-11-11, Revised : 2020-05-14, Accepted : 2020-05-22

\begin{abstract}
The research objective is to learn how to use contracts to minimize the success of smartphones while studying students at home. The study was conducted on 5 students of SMAN 3 Kota Tasikmalaya who were selected using proportional random sampling technique in one group pretest-posttest design experiment. Meanwhile, to analyze data using descriptive and nonparametric statistics. The results of the preliminary study showed that smartphones when studying students showed a category of users at risk. However, after the training is given it becomes a regular user category (increased), so students can take advantage of learning time easily and manage more readiness in overcoming learning in school. The trial results show significant results obtained by Asymp values. $\mathrm{Sig}=0.038<$ of a (0.05) then rejected means that there are differences in students using smartphone compilation learning at home before and followed by counseling using motivational contract techniques, using contract techniques proven effective to minimize smartphones based on student learning time at home. This shows the technique of a contract that can be agreed as one that asks for help and counseling in minimizing smartphones while studying.
\end{abstract}

Keywords: Contract Behavior; Smartphone Abuse; Study.

\section{Introduction}

The development of technology from time to time is growing rapidly. One of the biggest contributions of technology is delivering people in the digital age. In this digital age, the way individuals interact also changes to meet face to face is no longer the only way for individuals to interact because there are communication devices such as mobile phones or smartphones that can facilitate interaction (Hanika 2015). Mobile or better known as a smartphone is one proof of technological advances in the digital age. In Indonesia, the development of smartphones is not only used as a communication tool but has almost become a lifestyle in various communities, including teenagers. This fact is based on the statistical results of an estimated digital marketing research institute e-marketer in 2018 which stated that there were more than 100 million active smartphone users in Indonesia. With this amount, Indonesia will become the fourth-largest smartphone user country in the world after China, India, and America (Felix 2018).

At this time, almost all teenagers already have a smartphone, in fact most of them consider a smartphone as a very important item so that they are not uncommon to always take it wherever they go including to school. The use of smartphones among adolescents, especially students can influence the main task of learning. Students who often use gadgets during class time, can have an impact on the lack of concentration of students in absorbing the material explained by the teacher and this has an effect on academic grades in school, conversely students who rarely use gadgets have a high level of achievement (Beauty, Ismanto, and Onibala 2015). Furthermore, based on previous research conducted by Kibona and Mgaya in 2015 , the results were obtained that $75 \%$ of smartphone users are individuals under the age of 25 years, this shows that adolescents are more at risk of acts of misuse of smartphones than adults, in addition to that in their study of 100 students found that $48 \%$ of students tend to use smartphones around 5-7 hours per day, $65 \%$ of students use social media sites, such as Facebook, Twitter, Instagram, WhatsApp and the like without considering time, thus negatively impacting student academic performance, which can be seen from the GPA value of the majority of students who show grades below 3 (Lusekelo and Mgaya 2015). 
Basically, the use of a smartphone can have a positive impact on learning, but it does not rule out the possibility of also having a negative impact, therefore a fundamental understanding is needed related to the actual use of a smartphone (Lepp, Barkley, and Karpinski 2015). Utilization of technological development appropriately can affect children's development, including : (1) neurological development, technological media are very helpful in stimulating brain function and performance, the amount of information content provided by the media is absorbed by the brain and recorded in memory, so that it can develop and strengthen nerve connections in the brain; (2) watching films and educational games applications as one of the learning environments can stimulate a better mindset; (3) media and technology can influence verbal skills (language); (4) can facilitate communication and maintain a friendship even in distant circumstances; (5) the interrelationship of the existence of educational regulations on the use of technology can provide a direct positive relationship with student involvement and independent learning (Rashid and Asghar 2016). However, the lack of regulation in the use of smartphones without realizing it can have a negative impact, including: (1) disruption of fine and gross motor development of children, such as: sloppy writing or difficult to read, rarely engage in physical activities that can cause obesity and obesity ; (2) the number of shows that do not educate, causing moral shifts in children; (3) it is not uncommon to find children trapped in the preoccupation of digital media and gadgets that forget to interact with the surrounding environment, and this can cause disruption of social development (Santosa 2015).

Based on the results of a preliminary study of students and some teachers at SMAN 3 Kota Tasikmalaya, information was obtained that misuse of smartphones often occurs when learning takes place both at school or at home, especially when doing homework. Most students do this with the excuse of getting rid of drowsiness or just getting rid of the boredom of the amount of learning they get at school. The preoccupation that comes from using a smartphone causes students difficulty in controlling themselves so that the time that should be used for learning, is used up to play smartphone. In fact, some of the students also complained about the effects arising from the frequent use of smartphones, including: (1) disruption of eye health, such as: redness of the eyes, sore and minus the eyes increase. (2) taking up the time students have to rest and study at home, which can have an impact on learning in school that students lack the enthusiasm and readiness to learn sufficiently so that it can impact on the decline in student academic values; (3) Frequency of using a smartphone can shift the main tasks of students in learning, consequently the learning achievement of students at school decreases.

There is a gap that occurs in students of SMAN 3 Kota Tasikmalaya, so we need to recognize the factors that cause students to become smartphone users. Internal factors that describe individual characteristics and influence individuals so that they become addicted to smartphones can be seen from the following three aspects: (1) low self-control and difficulty in scheduling daily activities, individuals who have low self-control will let themselves do risky without thinking about the effects. (2) high sensation seeking nature, this aspect is a factor that describes an individual's psychological situation, such as: feeling psychologically similar when using a smartphone, feeling helpless when there is no smartphone even for a while, a feeling of loneliness and psychological anxiety often, and feel the dependence on smartphones. (3) low self esteem (Agusta 2016).

From the description above it can be seen that the misuse of smartphones among students of SMAN 3 Kota Tasikmalaya is caused by the lack of discipline and self-control that is possessed when using a smartphone during student learning. So based on some of the problems experienced by these students, it becomes the basis for consideration of the need for a technique that can reduce smartphone abuse and teach students to have a strong commitment so that they 
can discipline themselves and the time they have to carry out learning activities well, especially at home. One intervention that can be used is to use a contract behavior technique.

Content usage services with behavioral contracting techniques are able to show behavioral change, ie students not only have short-term life goals but have a clear life plan and value time more by reducing activities or activities that are less useful (Harlina et al. 2014). The use of behavioral contracting techniques is used to increase commitment and behavior change over excessive habits of using smartphones while studying students at home. It is hoped that by providing this technique, these disruptive behaviors can be minimized so that students can focus and maintain their motivation in carrying out their study assignments. This is in line with his opinion Erford dan Strawhun et all (Muslih 2019) that the awarding of a contract can be used to help academic problems by teaching students to intentionally do certain learning tasks under their control. In addition, learning contracts awarded to students can be an effective tool for developing and maintaining student motivation based on behavioral planning (Abdullah and Yih 2014).

Based on the explanation above, the purpose of this research is to test the behavior contract technique to minimize the misuse of smartphones while studying students at home. As for achieving these goals, the following steps are carried out: (1) knowing the profile of smartphone abuse during student learning at home, (2) knowing the implementation of counseling using contract behavior techniques in minimizing smartphone abuse in student learning time, (3) knowing the level of effectiveness of contract behavior techniques to minimize smartphone misuse when students study at home.

\section{Methods}

This research is experimental research. The design used is a pre-experimental (PreExperimental Design) with a design model using one group pretest-posttest design. This study also used "proportional random sampling", namely as a sampling technique. Samples taken are students who have problems in using smartphones, where these students are indicated to show user behavior risks to smartphones. The subjects in this study were 5 students who showed risky behavior of smartphone abuse at SMAN 3 Kota Tasikmalaya.

Data collection methods used in research are using questionnaires and interviews, while to analyze data using quantitative data analysis. In descriptive statistical research is used to get a picture of the level of smartphone abuse by students while studying through questionnaires, while the nonparametric technique used to test hypotheses is the Wilcoxon Signed rank test. This Wilcoxon test is used to find the difference between pretest and posttest using SPSS 16.0 application assistance. The decision-making method used is by comparing the probability value with an 'of 0.05 . If probability < $a$ 'is rejected, and if probability> $a$ ' is accepted.

\section{Results and Discussion}

The results and discussion of the research are presented by describing the findings in the field related to the purpose of conducting research, which is to test the use of behavioral contracting techniques as an effort to minimize the misuse of smartphones during student learning at home. These goals can be achieved through the following steps:

\section{Knowing the condition of smartphone abuse during student learning}

The condition of using a smartphone while studying is obtained from the results of the distribution of a standardized self-examination questionnaire on smartphone abuse in adolescents. Questionnaires were given to 5 subjects of students (MRR, GB, MS, RR, and AA) in class XI of SMAN 3 in Tasikmalaya City. The purpose of this questionnaire is to measure the level of smartphone abuse, especially when studying before and after the behavior contract technique is given, so that the results of the questionnaire distribution can be seen how much smartphone use is being carried out by students while studying. Meanwhile, the Questionnaire 
used consisted of 15 items of statements with a Likert scale model with a scale of 1-4 and 3 indicators, namely: (1) self-control and scheduling daily activities, (2) high sensation seeking nature and, (3) self-esteem.

The categories used to determine the level of misuse of smartphones are those of ordinary users, high risk and high risk. Categorizing is done by following some guidelines proposed by (Azwar 2014), as follows:

$\begin{array}{ll}X_{\min } & : \text { Lowest Value X Number of Items }=1 X 15=15 \\ X_{\max } & : \text { Most Value X Number of Items }=4 \text { X } 15=60 \\ \text { Range } & : X_{\max }-X_{\min }=60-15=45 \\ \text { Mean } & :\left(X_{\max }+X_{\min }\right): 2=(60+15): 2=37,5\end{array}$

SD (Standart Deviasi) : Range/ $6=7,5$

In detail the formulas / guides used in categorizing students who often use smartphones while studying, can be seen in the table below:

Table 1. Categorization Guide

\begin{tabular}{llc}
\hline \multicolumn{1}{c}{ Category } & \multicolumn{1}{c}{ Formula / Categorization Guide } \\
\hline Normal & $\mathrm{X}<\mathrm{M}-1 \mathrm{SD}$ & $\mathrm{X}<30$ \\
Risk & $\mathrm{M}-1 \mathrm{SD} \leq \mathrm{X}<\mathrm{M}+1 \mathrm{SD}$ & $30 \leq \mathrm{X}<45$ \\
High & $\mathrm{M}+1 \mathrm{SD} \leq$ & $45 \leq$ \\
\hline
\end{tabular}

Table 2. Pretest and Postest Abuse of Smartphones on Students

\begin{tabular}{ccccc}
\hline Name & $\begin{array}{c}\text { Pretest } \\
\text { Score }\end{array}$ & Category & Postest Score & Category \\
\hline MRR & 44 & Risk & 29 & Normal \\
GB & 42 & Risk & 29 & Normal \\
MS & 44 & Risk & 29 & Normal \\
RR & 43 & Risk & 28 & Normal \\
AA & 42 & Risk & 28 & Normal \\
Rata/Rata & 43 & Risk & 27,6 & Normal \\
\hline
\end{tabular}

Based on the pretest and posttest results table above, it can be seen that the subject is given counseling using contract techniques, the overall average score is based on an average score of 43 to 27.6. What is meant by general students is included in the category of smartphone users who are at risk. But after being given counseling using a student contract technique can be changed, namely by obtaining an average score of 28.6, which means that general students are included in the category of ordinary smartphone users.

\section{Implementation of contract behavior techniques to minimize misuse of smartphones during student learning}

The implementation of the behavioral contracting technique used to minimize smartphone misuse during student learning time is carried out using a behavioral counseling stage consisting of, the assessment phase, setting goals, implementing techniques and evaluating-end (Nelson- Jones 2011). Behavioral counseling in the study was conducted for 6 meetings with 60 minutes duration of the counseling session. In its implementation counseling begins with the main assessment session, which is used to find and explore information about students and problems that cause misuse of smartphones conducted by students, then proceed with subsequent sessions determined by the nature of the client's problem and follow the plans that have been determined or agreed upon by Researchers (Counselors) and Students, and end with a follow-up session or follow-up after the provision of behavioral counseling using a contract behavior technique ends. 
The nature of the problems discussed in counseling sessions is based on indicators of misuse of smartphones, including First session: identification and handling of problems of misusing smartphone behavior during learning; Second session: identifying and handling lack of self-control and scheduling students' daily activities; Third session: identification and handling of the high nature of sensation seeking; Fourth session: identification and handling of students' low self-esteem; Fifth session: identifying and optimizing the ability of students to use smartphones appropriately; Sixth Session: Follow-up or follow-up after the provision of behavioral counseling using the behavioral contract technique ends using the questionnaire used at the time of the pretest.

In implementing the techniques in counseling, the use of contract techniques used in this study in the following steps:

a. Formulating the contents of the contract, at this stage the teacher and students carry out the following activities: (1) identification of the behavior or habits of using smartphones while studying; (2) determining the target behavior to be changed, namely the lack of selfcontrol of students when using a smartphone during study time and helping students in scheduling learning activities at home; (3) determine the method to be used in minimizing the use of smartphones while studying at home, which includes: in the first week students must use the time they have to study for at least 60 minutes per day and during the learning process takes place students are not allowed to use smartphones, in the second week student study time at home is increased to a minimum of 90 minutes per day and it is also not permissible to use a smartphone while studying; (4) choose or determine a third party that has the task to help students optimize the achievement of the expected counseling goals, namely students are able to minimize the abuse of smartphones in student learning time. the five students choose the family as the party that will help them carry out their plan.

b. Pour/fill out the contract and sign it either by the teacher guidance and counseling, students, or third parties (the student's family). To facilitate the making of the contract, there are several tools used, namely: (a) activity plan sheet which includes a series of student learning activities without smartphone interruption, (b) determination of the form of reinforcement using the reward/punishment questionnaire, which is used when students succeed / not in carrying out the plan. In implementing the determination of reward/punishment students are given the freedom to determine it independently with the approval of the BK Teachers and the family.

c. Give copies of letters to students and teachers for guidance and counseling.

d. Establish an evaluation meeting to monitor the progress of the contract and every meeting every aspect of the contract is examined

e. Deciding when the contract ends. In its implementation students must always be monitored and receive feedback, either in the form of assistance or direction from the teacher's guidance and counseling (T. Erford 2016).

In more detail, to see the results of the implementation of the behavioral contract technique in minimizing the misuse of smartphones during student learning, it can be explained as follows:

a. First-week counseling evaluation results.

In the first week students have a minimum of 60 minutes of learning tasks per day and during the learning process students are not allowed to use smartphones. The results of evaluating the implementation of the counseling process in the first week obtained the results as shown in the graph below: 


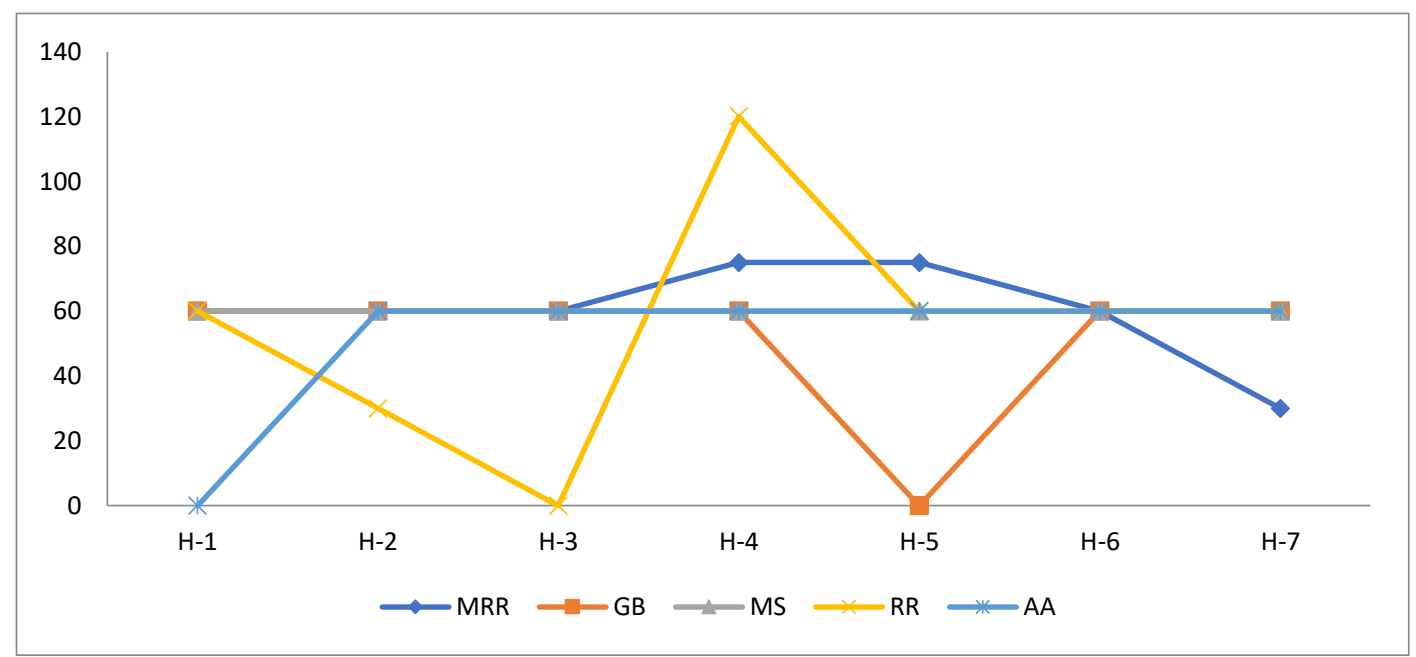

Graph 1: Results of the First Week Counseling Evaluation

Based on graph 1 above, it can be seen that only MS shows consistency in learning without smartphone interruption and obtains rewards agreed in the contract. The other four students namely MRR, GB, RR, and AA still show instability or inconsistency in carrying out contract activities, instability in the initial sessions of contract activities is possible because students do not have a strong commitment to learning to change the habit of using excessive smartphones while studying, so students have difficulty being able to adapt to the agreed assignment or activity plan. The inability of the four students to carry out their duties then make the four students get punishment in accordance with the agreement in the contract.

b. Second week counseling evaluation results.

In the second week of counseling, students have an assignment to study for a minimum of 90 minutes per day and during the learning process students do not use to use a smartphone. The results of the counseling in the second week can be seen in the graph below:

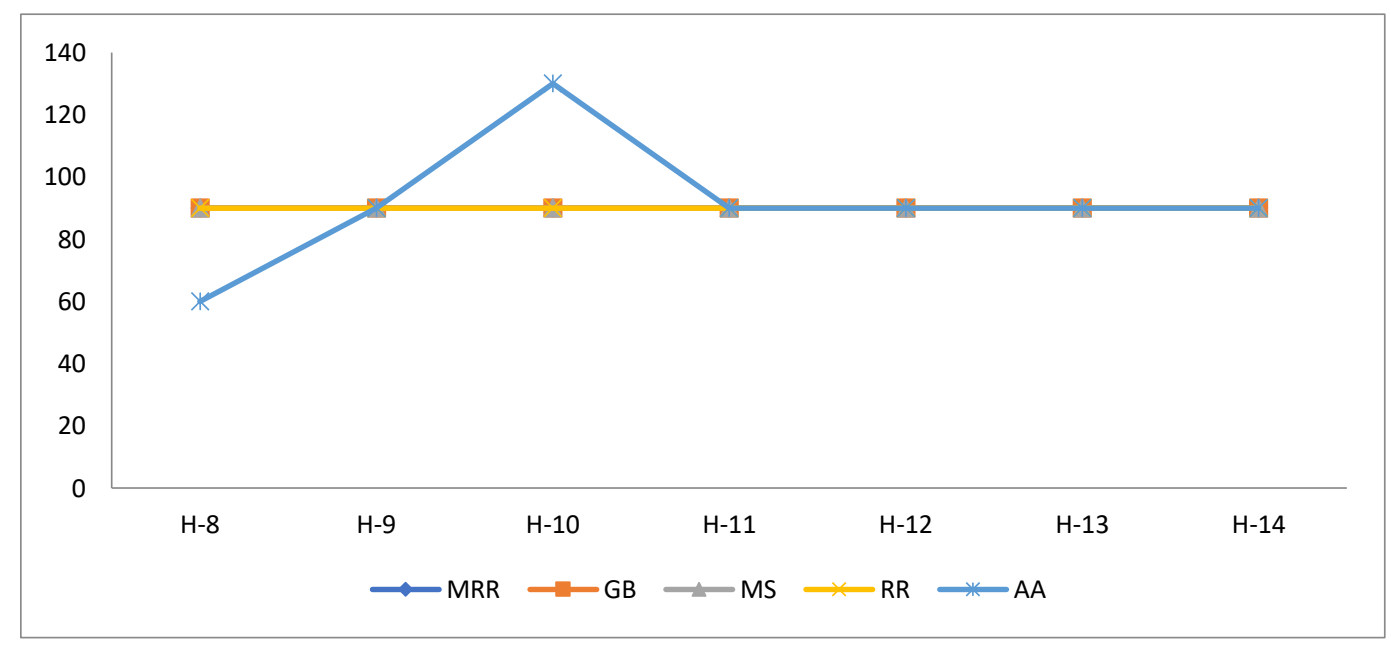

Graph 2: Results of the Second Week Counseling Evaluation.

In graph 2 above, it is recognized as four students (MRR, GB, MS, RR) who can be relied upon to carry out learning activities without a smartphone problem, so they are entitled to prizes according to the contents of the agreed contract. While AA, still involves instability or inconsistency in carrying out contract activities, instability in contract activities due to 
differences in certain interests such as family events, so that the planned activities can be controlled or increased. Judging from the results of the evaluation in the second week, AA has not been able to optimize it to carry out the agreed duty, so that it results in the granting of difficulties or penalties that have been agreed upon.

c. Final Counseling Evaluation Results

The third week of the counseling process, students no longer use the contract as a control in learning, but in this third week, the guidance and counseling teacher gives students the freedom to use the time they have by studying as much as possible without smartphone interference and without the time limit specified. The purpose of the counseling process at this stage is to see the consistency of students in carrying out learning activities at home without smartphone interruption. Visually the results of the final evaluation of the counseling process in the third week can be seen in the graph below:

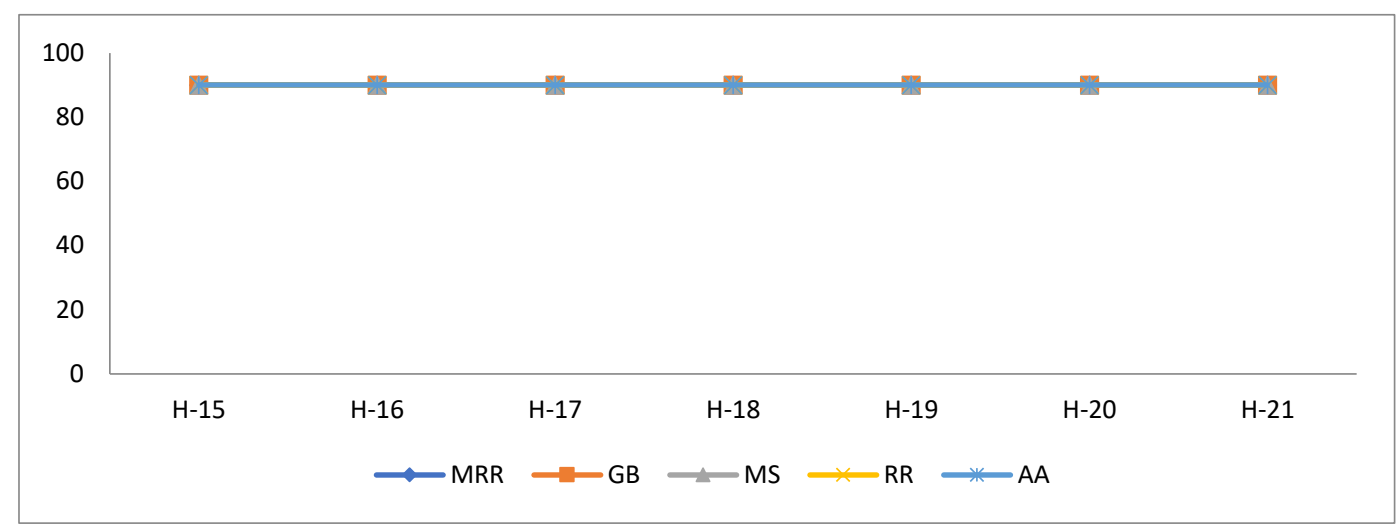

Graph 3: Final Evaluation Results (follow up)

Graph 3 above, shows the final evaluation conducted at the counseling session using the behavior contract technique. The final evaluation is used to see the stability or consistency of students in conducting learning activities without smartphone interference. Based on graph 3 above, it can be explained above the follow-up evaluation of counseling activities using contract techniques used to minimize smartphones during student learning at home shows that all students use stability or can assist in learning minutes per day. That is, this gives an understanding of the existence of the stability shown by students. In other words, students already have a commitment to using smartphones while studying.

Based on the results of the application of counseling in research, it shows that with contract behavior techniques students are taught to discipline themselves, make commitments and utilize the time they have to carry out learning activities as well as possible, so that gradually from their learning students can be consistent and accustomed to learning without smartphone interference.

The success of the implementation of counseling with contract behavior techniques can not be separated from several factors, namely the high willingness of students to learn to discipline themselves and take advantage of the learning time they have and instill it as a commitment. The existence of such learning, students can concentrate fully on learning and provide benefits that can be felt directly by students, such as students are better prepared to face the lessons at school, get good grades, dare to express opinions in front of the class and can do school work as well as possible. In addition, the role of the BK teacher also has a very important role as a motivator and direction in each contract implementation. Similarly, third parties (families) must be able to provide motivation and firmness in providing rewards or punishment. So that the fabric of good cooperation between counselors, students, and third parties will determine the success of counseling. From the results of the research conducted, in 
line with the results of research from Aprilia et al in 2014, that the application of cognitive counseling with contracting techniques (contingency contracting) is effectively used to increase student concentration because cognitive counseling can provide an understanding of the way individuals think so that they have a reference in increasing concentration on proper learning (Aprilia, Suranata, and Dharsana 2014). In addition, the behavioral contract technique can also improve the discipline of children which include: obeying agreed rules, arriving on time, being able to complete tasks to completion, using objects according to their functions, taking and returning objects according to their place, and orderly waiting their turn (Wahyuni 2016).

The success shown by the results of the counseling process that has been done does not rule out the possibility of several obstacles encountered in achieving the counseling goals that have been agreed upon include: the first week found several students who lack commitment and consistency in carrying out their duties, other than that in the week to two were found to be some activities outside the control of students such as: family events, so that caused students to not be able to carry out their duties optimally. The gap that occurs in counseling conducted, according to Amalia et al in his 2016 research stated that the learning commitments students have can be seen from the following five aspects of learning: (1) commitment to reading for pleasure or reading for entertainment can be low, due to students not providing time to read (study) either in the library or at home and tend to use the internet more as a place to get entertainment; (2) homework or homework (PR) commitment is low because students prefer watching TV or playing smartphones rather than doing homework and prefer to see other people's homework results rather than doing it themselves; (3) commitment to learning school engagement or involvement in school is low due to the lack of readiness of students in receiving subject matter, so they are reluctant to be active or ask questions to the teacher, and prefer to avoid when asked to try or do something; (4) achievement motivation or achievement motivation. This commitment will look high when students have the determination to be sincere without the rewards of learning; (5) bonding to school bonding to school or attachment to school, will show as a high commitment when students have a concern for the school (Amalia et al. 2016).

\section{Knowing the level of effectiveness of contract behavior techniques to minimize smartphone misuse when students study at home}

The steps to find out the effectiveness of the behavioral contract technique to minimize smartphone misuse when studying at home is done by analyzing data using descriptive and nonparametric statistics. The results of a descriptive analysis on quantitative and qualitative data indicate a change in scores, from risk users to normal users, followed by changes that are shown by students every time they attend each counseling session. Furthermore, to find out the statistical test results from the use of behavioral contract techniques to minimize smartphone misuse when studying at home, it can be seen in the table below:

Table 3: Statistical Test

\begin{tabular}{lr}
\hline & After-before \\
$\mathbf{Z}$ & $-2.070^{\mathrm{a}}$ \\
Asymp. Sig. (2- & .038 \\
tailed) & .038 \\
\hline
\end{tabular}

From the table above we get the Asymp value. Sig $=0.038$. The critical area is rejected if the Asymp value. Sig <value a. Thus, because of the Asymp value. Sig $=0.038<$ of a (0.05) then it is rejected which means that there are differences in the attitudes of students in using 
smartphones when studying at home before and after the following counseling using the behavior contract technique.

Thus, the results of this study indicate that effective behavioral contracting techniques can minimize the misuse of smartphones while studying students at home. Thus, the contract behavior technique can be used by counselors in minimizing the behavior of misuse of smartphones while studying students at home.

\section{Conclusions and Suggestions}

Based on the results of research and discussion, it was concluded that the use of effective behavioral contracting techniques can minimize inappropriate behavior such as misuse of smartphones while studying at home, that is by teaching discipline in using smartphones and teaching the use of time to learn as well as possible and instill it as a commitment, from the learning gradually it is hoped that students will be able to be consistent and make the behavior that they learn become a habit. The successful implementation of contract behavior techniques in counseling is strongly influenced by several factors, namely the willingness of students to learn discipline and instill it as a commitment, the counselor must be able to provide motivation and direction in each contract implementation and be able to establish good cooperation between students and third parties in order to achieve counseling goals, third parties (friends, parents/guardians, and people closest to students) must be able to provide motivation and firmness in providing reward or punishment.

Through this research, researchers propose a number of suggestions, namely for counselors or teachers guidance and counseling, should continue to improve the skills possessed both in the use of contract behavior techniques or other techniques deemed useful to assist clients or students in optimizing their abilities in learning in school and for further readers and researchers to be able to utilize every information in this study, as reference material or references for further research, as well as basic materials in the preparation and development of guidance and counseling service materials.

\section{References}

Abdullah, Aidora and Tan Yeong Yih. 2014. "Implementing Learning Contracts in a Computer Science Course as a Tool to Develop and Sustain Student Motivation to Learn." Procedia Social and Behavioral Sciences 123:256-65.

Agusta, Duha. 2016. "Faktor-Faktor Resiko Kecanduan Menggunakan Smartphone." E-Journal Bimbingan Dan Konseling 5(3):86-96.

Amalia, Dita, Moch Dimyati, and Happy Karlina Marjo. 2016. "Profil Komitmen Belajar Siswa Kelas VIII Di Sekolah Menengah Pertama Taruna Bhakti Depok." Jurnal Bimbingan Konseling 5(1):43-50.

Aprilia, Diana, Kadek Suranata, and Ketut Dharsana. 2014. "Penerapan Konseling Kognitif Dengan Teknik Pembuatan Kontrak (Contigency Contracting) Untuk Meningkatkan Konsentrasi Belajar Siswa Kelas X TKR1 SMK Negeri 3 Singaraja." E-Journal Undiksa 2(1):1-10.

Azwar, Saefuddin. 2014. Penyususnan Skala Psikologis. Edisi kedu. Yogyakarta: Pustaka Pelajar.

Beauty, Manumpil, Yudi Ismanto, and Franly Onibala. 2015. "Hubungan Penggunaan Gadget Dengan Tingkat Prestasi Siswa Di Sma Negeri 9 Manado." Jurnal Keperawatan 3(2):1-6.

Felix, A. 2018. "Fenomena Gadget Di Kalangan Remaja. Retrieved January 24, 2019."

Hanika, Ita Musfirowati. 2015. "Fenomena Phubbing Di Era Milenia (Ketergantungan Seseorang Pada Smartphone Terhadap Lingkungannya)." Interaksi: Jurnal Ilmu Komunikasi 4(1):42-51.

Harlina, Anisa Puji, Suharso, Maria Theresia, and Sri Hartati. 2014. "Mengembangkan 
Kemampuan Manajemen Waktu Melalui Layanan Penguasaan Konten Dengan Teknik Kontrak Perilaku." Indonesian Journal of Guidance and Counseling: Theory and Application 3(3):38-43.

Lepp, Andrew, Jacob E. Barkley, and Aryn C. Karpinski. 2015. "The Relationship between Cell Phone Use and Academic Performance in a Sample of U.S. College Students." SAGE Open 5(1):1-9.

Lusekelo, Kibona and Gervas Mgaya. 2015. "Smartphones' Effects on Academic Performance of Higher Learning Students." Journal of Multidisciplinary Engineering Science and Technology 2(4):777-84.

Muslih, Yuyun Nuriyah. 2019. Kontrak Belajar. 1st ed. edited by T. Pena. Kuningan: Goresan Pena.

Nelson- Jones, Richard. 2011. Teori Dan Praktik Konseling Dan Terapi. Edisi Keen. edited by Pustaka Pelajar. Yogyakarta.

Rashid, Tabassum and Hanan Muhammad Asghar. 2016. "Technology Use, Self-Directed Learning, Student Engagement and Academic Performance: Examining the Interrelations." Computers in Human Behavior 63:604-12.

Santosa, Elisabet. 2015. Raising Children in Digital Era. Jakarta: Gramedia.

T. Erford, Bradley. 2016. 40 Teknik Yang Harus Diketahui Setiap Konselor. Kedua. Yogyakarta: Pustaka Pelajar.

Wahyuni, Septi. 2016. "Peningkatan Kedisiplinan Siswa Melalui Teknik Kontrak Perilaku (Behavior Contract) Di TK ABA Pakis." Jurnal Pendidikan Anak Usia Dini 3(5):270-78. 